\title{
Multiplex-PCR for diagnosis of bacterial meningitis
}

\author{
Renata Chaves Albuquerque ${ }^{1}$ Ana Carolina Ramos Moreno ${ }^{1,2}$. Silvia Regina dos Santos ${ }^{3}$. \\ Selma Lopes Betta Ragazzi ${ }^{3}$. Marina Baquerizo Martinez ${ }^{1}$
}

Received: 7 August 2018 / Accepted: 17 December 2018 / Published online: 22 February 2019

(C) Sociedade Brasileira de Microbiologia 2019

\begin{abstract}
Considering the great lethality and sequels caused by meningitis, rapid diagnosis and prompt treatment initiation have a great impact on patient outcome. Here, we developed a multiplex-PCR for simultaneous detection of the four most prevalent bacterial pathogens directly in CSF samples. The multiplex-PCR was designed to detect the following genes: $f b s A$ (Streptococcus agalactiae), lytA (Streptococcus pneumoniae), crtA (Neisseria meningitidis), p6 (Haemophilus influenzae), and 16S rRNA (any bacterial agent). The multiplex-PCR showed a DNA detection limit of $1 \mathrm{pg} / \mu \mathrm{L}$. Among $447 \mathrm{CSF}$ samples tested, 40 were multiplex-PCR positive, in which 27 and 13 had positive and negative bacterial culture, respectively. Our multiplex-PCR is fast, reliable, and easily implementable into a laboratory routine for bacterial meningitis confirmation, especially for patients who previously started antimicrobial therapy. Our molecular approach can substantially improve clinical diagnosis and epidemiological measures of meningitis disease burden.
\end{abstract}

Keywords Meningitis $\cdot$ Multiplex-PCR $\cdot$ Cerebrospinal fluid samples $\cdot$ Bacterial pathogens

\section{Introduction}

Bacterial meningitis is one of the major infectious processes of the central nervous system (CNS) and consists in an inflammation of the protective membranes covering the brain and spinal cord due to bacterial infection of the cerebrospinal fluid (CSF) [1]. Several bacterial species are related to meningitis, and the leading causes around the world include Neisseria meningitidis, Haemophilus influenzae, Streptococcus pneumoniae, and Streptococcus agalactiae [1, 2]. Patients' susceptibility to pathogens seems to be related to age, where

Responsible Editor: Jorge Sampaio.

Ana Carolina Ramos Moreno

carol@usp.br

1 Faculdade de Ciências Farmacêuticas, Department of Clinical Chemistry and Toxicology, Universidade de São Paulo (USP), São Paulo, Brazil

2 Biomedical Sciences Institute, Vaccine Development Laboratory, Department of Microbiology, USP, São Paulo, Brazil

3 Hospital Universitário, USP, São Paulo, Brazil it is possible to find certain pathogens affecting groups of neonates, children from 1 month to 15 years old, and adults [3-8]. Usually, from 0 to 30 days of life, the major etiological agents are Listeria monocytogenes, S. agalactiae, Escherichia coli, and other bacteria from Enterobacteriaceae [7]. In the age of 1 month to 15 years, the most frequent agents are $H$. influenzae, N. meningitidis, and S. pneumoniae [4, 6], while in adults are $N$. meningitidis and $S$. pneumoniae $[5,8]$.

When the patient presents signs and suggestive symptoms of meningitis, physicians promptly request the lumbar puncture of the CSF to accomplish the diagnosis of the disease. CSF should be analyzed immediately, including physical, cytological, biochemical, microbiologic, and immunologic parameters [1,9]. Given the high mortality of bacterial meningitis, starting antimicrobial therapy and carrying out the diagnostic process should be done simultaneously in most cases. Frequently, the treatment must begin as soon as possible, even before lumbar puncture of the CSF [1, 2]. This procedure makes it difficult to confirm the diagnosis by inhibiting the growth of the bacterial pathogen in the microbiology laboratory. Nevertheless, confirmation of the diagnosis must not delay antimicrobial therapy [10]. Therefore, the development of rapid diagnostic tests which detect a range of common bacterial-causing meningitis has been highly recommended by physicians and public health organizations. 
To diagnose bacterial meningitis, CSF examination is mandatory. The CSF culture is the "gold standard" for diagnosis and obligatory to obtain the in vitro susceptibility of the causative microorganism and to rationalize an appropriate antimicrobial therapy [3]. At the clinical laboratory, CSF Gram staining assists in the presumptive diagnosis of the microorganism in 50-90\% of cases while CSF culture is positive in approximately $80 \%$ of the samples from untreated patients [9]. However, the sensitivity of Gram staining significantly decreases when patient is under antimicrobial therapy prior to obtaining the CSF sample. Additionally, latex particle agglutination tests can also assist in the presumptive diagnosis of the microorganism, detecting antigens of $N$. meningitidis, $H$. influenzae, S. pneumoniae, and S. agalactiae [11]. Although the latex particle agglutination tests seems to be more sensitive than Gram staining and bacterial culture in identifying fastidious organisms, the combinations of these techniques have a greater diagnostic potential [11]. However, the incremental yield of CSF Gram staining and latex particle agglutination tests is sometimes limited.

In recent decades, molecular methods, such as polymerase chain reaction (PCR), have provide additional aid in recognizing etiological pathogens of meningitis [12-16]. Molecular tools have been shown to be fast, cheap, and efficient in identifying different microorganisms, such as bacteria, viruses, or fungi. Regarding bacterial meningitis, a repertoire of research works reported that molecular diagnostic methods can be sensitive and specific for different organisms and can be applied to detect pathogens in CSF samples from patients in whom cultures remain negative or those who were pretreated with antimicrobials. Moreover, one of the great advantages of PCR is the use of a small volume of clinical sample for the molecular assay.

In the present work, we developed a multiplex-PCR for simultaneous detection of the leading causes of bacterial meningitis, being $H$. influenzae, $N$. meningitidis, S. agalactiae, and $S$. pneumoniae. Moreover, other possible bacterial pathogens can also be detected using the 16S rRNA gene in the multiplex-PCR. This diagnostic test was fast, reliable, and easily implementable into a laboratory routine. This molecular approach can considerably improve clinical diagnosis and epidemiological measures of meningitis disease burden.

\section{Material and methods}

\section{Clinical specimens}

The CSF samples were obtained from the Academical Hospital of University of São Paulo (Hospital Universitário da Universidade de São Paulo - HU-USP) and from the Institute of Infectology Emílio Ribas
(Instituto de Infectologia Emílio Ribas - IIER). This study was approved by the Ethics Committee of the HU-USP (protocol number 45904) and the IIER (protocol number 3807). The CSF samples were collected by lumbar puncture by specialized professionals and sent to the hospital clinical laboratory for microbiological, biochemical, cytological, and immunological analyzes. An aliquot of CSF samples was separated to be used in the multiplex-PCR diagnostic test. A total of $447 \mathrm{CSF}$ samples were analyzed, being 27 positives and 420 negatives for bacteriological culture (Table 1). The samples were divided in three groups (G I, G II, G III) according to CSF biological parameters (Table 2 ).

\section{Bacterial strains and culture methods}

The clinical isolates of $N$. meningitidis, $H$. influenzae, $N$. gonorrhoeae, S. agalactiae, S. pneumoniae, S. pyogenes, Enterococcus faecalis, S. aureus, L. monocytogenes, Pseudomonas aeruginosa, Salmonella Typhi, E. coli, Citrobacter koseri, Klebsiella pneumoniae, and Shigella flexneri used during PCR standardization were provided by the HU-USP. They were store at $-80^{\circ} \mathrm{C}$ in Tryptic Soy Broth (TSB) (Oxoid) with $15 \%$ of glicerol. They were cultured on chocolate blood agar and incubated at $37{ }^{\circ} \mathrm{C}$ for 18 to $48 \mathrm{~h}$ with $5 \% \mathrm{CO}_{2}$, before DNA extraction.

\section{CSF sample procedure for the multiplex-PCR assay}

The CSF samples were aliquoted into microtubes in a volume of $50 \mu \mathrm{L}$ or lower. The samples were then boiled for $15 \mathrm{~min}$, followed by an ice bath thermal shock for an additional $15 \mathrm{~min}$. These samples were then stored in freezer $-25{ }^{\circ} \mathrm{C}$ for their subsequent use in the multiplex-PCR assay.

Table 1 Cerebrospinal fluid samples from hospitals

\begin{tabular}{llll}
\hline $\begin{array}{l}\text { Bacteriological culture } \\
\text { results }\end{array}$ & $\begin{array}{l}\text { No. of samples } \\
\text { from HU-USP }\end{array}$ & $\begin{array}{l}\text { No. of samples } \\
\text { from IIER }\end{array}$ & $\begin{array}{l}\text { Total of } \\
\text { samples }\end{array}$ \\
\hline $\begin{array}{l}\text { Haemophilus influenzae } \\
\text { Neisseria meningitidis }\end{array}$ & 0 & 0 & 0 \\
Streptococcus agalactiae & 0 & 0 & 11 \\
Streptococcus pneumoniae & 12 & 0 & 0 \\
Pseudomonas aeruginosa & 2 & 1 & 13 \\
Klebsiella pneumoniae & 1 & 0 & 2 \\
Negative culture & 412 & 0 & 1 \\
Total of samples & 438 & 8 & 420 \\
\hline
\end{tabular}

HU-USP, Hospital Universitário da Universidade de São Paulo (Academical Hospital - University of São Paulo); IIER, Instituto de Infectologia Emílio Ribas (Institute of Infectology Emílio Ribas) 
Table 2 Classification of CSF by biological parameters and main pathological alterations

\begin{tabular}{|c|c|c|c|}
\hline Group & $\begin{array}{l}\text { No. of } \\
\text { samples } \\
\text { (total) }\end{array}$ & $\begin{array}{l}\text { Bacterial } \\
\text { culture }\end{array}$ & Clinical parameters (No. of samples) \\
\hline G I & 27 & + & $\begin{array}{l}\text { Cytology } \geq 100 \mathrm{~mm}^{3}, \text { protein } \geq 40 \mathrm{mg} / \mathrm{dL} \\
\text { glucose } \leq 40 \mathrm{mg} / \mathrm{dL}, \\
\text { polymorphonuclear cells } \geq 50 \% \text {, latic } \\
\text { acid } \geq 40 \mathrm{mg} / \mathrm{dL}, \text { positive latex } \\
\text { agglutination and/or direct gram stain- } \\
\text { ing ( } 27 \text { samples) }\end{array}$ \\
\hline G II & 389 & - & $\begin{array}{l}\text { Cytology } \geq 100 \mathrm{~mm}^{3}, \text { protein } \geq 40 \mathrm{mg} / \mathrm{dL} \\
\text { glucose } \leq 40 \mathrm{mg} / \mathrm{dL}, \\
\text { polymorphonuclear cells } \geq 50 \% \text {, latic } \\
\text { acid } \geq 40 \mathrm{mg} / \mathrm{dL}, \text { positive latex } \\
\text { agglutination and/or direct gram stain- } \\
\text { ing ( } 376 \text { samples with one or more of } \\
\text { these clinical parameters and } 13 \text { sam- } \\
\text { ples with all these clinical parameters) }\end{array}$ \\
\hline G III & 31 & - & $\begin{array}{l}\text { No biochemical or cellular alterations that } \\
\text { could suggest a bacterial meningitis ( } 31 \\
\text { samples) }\end{array}$ \\
\hline
\end{tabular}

\section{Bacterial DNA extraction}

The total DNA from $H$. influenzae, $N$. meningitidis, $S$. agalactiae, and $S$. pneumoniae was extracted by the Wizard (® Genomic DNA purification kit (Promega, Madison, USA) according to manufacturer's instructions. The extracted DNAs were quantified by NanoDrop ND, diluted to different concentrations for the evaluation of the sensitivity and specificity of the multiplex-PCR proposed diagnostic test.

\section{Clinical bacterial lysates}

The clinical isolates of $N$. meningitidis, $H$. influenzae, $N$. gonorrhoeae, S. agalactiae, S. pneumoniae, S. pyogenes, Enterococcus faecalis, S. aureus, L. monocytogenes, P. aeruginosa, Salmonella Typhi, E. coli, C. koseri, K. pneumoniae, and Shigella flexneri were cultured on chocolate blood agar and subcultivated in TSB until they reach an absorbance of 0.08 to 0.10 achieved at $625 \mathrm{~nm}$. An aliquot of $10 \mu \mathrm{L}$ of resuspended bacteria was transferred to a tube containing $60 \mu \mathrm{L}$ of sterile reagent grade water. The samples were then boiled for $15 \mathrm{~min}$, followed by an ice bath thermal shock for an additional $15 \mathrm{~min}$, and were subsequently stored at $25{ }^{\circ} \mathrm{C}$ for subsequent use in the multiplex-PCR assay.

\section{Multiplex-PCR primers and reaction conditions}

The primers used in multiplex-PCR are specified in Table 3. Primers used to amplify the capsular transport gene $c r t A$ from
$N$. meningitidis and the autolysin gene lytA from $S$. pneumoniae were obtained from literature $[12,17]$. Specific primers for the following targets were designed based on DNA sequences deposited in GeneBank: 16S rRNA gene, the outer membrane protein gene $p 6$ from $H$. influenzae, and fibrinogen receptor gene $f b s A$ from $S$. agalactiae. MultiplexPCR was performed in a $20 \mu \mathrm{L}$ reaction volume, containing $0.4 \mu \mathrm{M}$ of each primer, except for the $16 \mathrm{~S} r R N A$ gene $(0,2 \mu \mathrm{M}$ of each primer), $150 \mu \mathrm{M}$ (each) deoxyribonucleoside triphosphates, $1.5 \mathrm{mM}$ of $\mathrm{MgCl}_{2}, 2 \mu \mathrm{L}$ of tenfold-concentrated polymerase synthesis buffer, $1.5 \mathrm{U}$ of Taq DNA polymerase (Fermentas Life Sciences), and $2 \mu \mathrm{L}$ of DNA template. The PCR conditions included denaturation for $30 \mathrm{~s}$ at $95^{\circ} \mathrm{C}$, annealing for $30 \mathrm{~s}$ at $60{ }^{\circ} \mathrm{C}$, and extension for $60 \mathrm{~s}$ at $72{ }^{\circ} \mathrm{C}$ for 40 cycles. PCR products were separated on a $1.5 \%(\mathrm{wt} / \mathrm{vol})$ agarose gel for $1.5 \mathrm{~h}$ at $9.5 \mathrm{~V} / \mathrm{cm}$ and visualized after ethidium bromide staining. A 100-bp DNA ladder (Invitrogen) was used as an external fragment size standard.

\section{Multiplex-PCR specificity assessment}

To test the specificity of the multiplex-PCR diagnostic test, we used different clinical isolates ( $N$. meningitidis, H. influenzae, $N$. gonorrhoeae, S. agalactiae, S. pneumoniae, S. pyogenes, E. faecalis, $S$. aureus, L. monocytogenes, $P$. aeruginosa, Salmonella Typhi, E. coli, C. koseri, K. pneumoniae, and Shigella flexneri as well as six samples of CSF positive for Cryptococcus neoformans and two samples of CSF positive for Candida albicans). For the clinical isolates, we used bacterial lysates as DNA template, while CSF samples were treated as described above.

\section{Evaluation of multiplex-PCR diagnostic test performance}

The diagnostic accuracy of the multiplex-PCR was evaluated by positive percent agreement (PPA) and negative percent agreement (NPA), calculated in accordance with the "Statistical Guidance on Reporting Results from Studies Evaluating Diagnostic Tests" from the Food and Drug Administration (FDA). The PPA and NPA refer to the extent of agreement between the outcome of the multiplex-PCR and the non-reference standard, which was the isolation of pathogens by microbiological culture. For the mathematical calculation, we use the following formula: PPA $=100 \% \times a /(a+c)$ and NPA $=100 \% \times d /(b+d) ; a=$ non-reference standard positive and multiplex-PCR positive; $b=$ non-reference standard negative and multiplex-PCR positive; $c=$ non-reference standard positive and multiplex-PCR negative; $d=$ non-reference standard negative and multiplex-PCR negative. The kappa coefficient $(95 \% \mathrm{CI})$ was analyzed using Microsoft Excel. The results may vary from -1 to +1 . Values smaller than 0.2 mean small agreement, values between 0.21 and 0.40 are 
Table 3 Primers used in multiplex-PCR reaction

\begin{tabular}{|c|c|c|c|c|}
\hline Target Gene & Bacterial species & Sequence $\left(5^{\prime} \rightarrow 3^{\prime}\right)$ & Amplicon (bp) & Reference \\
\hline p6 & Haemophilus influenzae & $\begin{array}{l}\text { Foward - ACGATGCTGCAGGCAATGGT } \\
\text { Reverse - ATACTTTAGCAGCTGGCGTTGC }\end{array}$ & 177 & This study \\
\hline crtA & Neisseria meningitidis & $\begin{array}{l}\text { Foward - GCTGCGGTAGGTGGTTCAA } \\
\text { Reverse - TTGTCGCGGATTTGCAACTA }\end{array}$ & 110 & {$[12]$} \\
\hline$f b s A$ & Streptococcus agalactiae & $\begin{array}{l}\text { Foward - AGAGCGTCGTCAACGTGATGC } \\
\text { Reverse - AAGTCACCCTAACCAACCTAA }\end{array}$ & 529 & This study \\
\hline lytA & Streptococcus pneumoniae & $\begin{array}{l}\text { Foward - GGCTACTGGTACGTACATTC } \\
\text { Reverse - AATCAAGCCATCTGGCTCTA }\end{array}$ & 395 & [17] \\
\hline $16 S r R N A$ & universal & $\begin{array}{l}\text { Foward - CAGCAGCCGCGGTAATAC } \\
\text { Reverse - ACCAGGGTATCTAATCCTGT }\end{array}$ & 283 & This study \\
\hline
\end{tabular}

$b p$, base pairs

fair agreement, values between 0.41 and 0.60 are of moderate agreement, values between 0.61 and 0.80 are of substantial agreement, and values between 0.81 and 1.00 reflect near perfect agreement [18].

\section{Results}

\section{The multiplex-PCR assay showed specific amplification of all targets}

The targeted etiological agents in this study were $H$. influenzae, $N$. meningitidis, S. agalactiae, and $S$. pneumoniae. The multiplex-PCR reaction designed in this study efficiently amplified the crtA ( $N$. meningitidis), lytA (S. pneumoniae), p6 (H. influenzae), fbsA (S. agalactiae), and $16 S r R N A$ genes (Fig. 1). For the evaluation of the multiplex-PCR specificity, we tested a broad of clinical bacterial isolates. Unspecific amplification products were observed when $S$. aureus, $P$. aeruginosa, $K$. pneumoniae, $C$. koseri, and $N$. gonorrhoeae were tested, but none of them with the same size as those observed for the target genes $l y t A$, $C r t A, f b s A$, and $p 6$. Of note, unspecific bands had a much lower intensity then those observed with specific targets (Fig. 2). The amplicons corresponding to the $16 S$ rRNA gene were detected for all bacterial species. No amplification was detected using CSF samples positive for fungi.

\section{The lower detection limit of the multiplex-PCR designed in this study is $1 \mathrm{pg} / \mu \mathrm{L}$}

To determine the lower detection limit of the multiplex-PCR assay, we evaluated decreasing concentrations of purified genomic DNA from $S$. pneumoniae, $H$. influenzae, S. agalactiae, and N. meningitidis, in a range from $1000 \mathrm{pg} /$ $\mu \mathrm{L}$ to $0.1 \mathrm{pg} / \mu \mathrm{L}$ per reaction. For the four pathogens targeted in this assay, the limit of detection was $1 \mathrm{pg} / \mu \mathrm{L}$ (Fig. 3).

\section{The multiplex-PCR test detected bacterial DNA in both culture-positive and culture-negative CSF samples}

The multiplex-PCR test was applied in 447 CSF samples (Table 1). The CSF samples were divided according to clinical parameters and bacterial culture data (Table 2). For the clinical samples positive for bacterial culture (group I), all 27 samples were also positive for multiplex-PCR. Of these samples, 11 were identified as $N$. meningitidis, 13 as $S$. pneumoniae, and three were positive only for the $16 S r R N A$ gene (Table 4). The three bacteria detected only by the $16 \mathrm{~S} r R N A$ gene were identified as $K$. pneumoniae (one isolate) and P. aeruginosa (two isolates) (Table 4). Concerning the clinical samples negative for bacterial culture (group II), $13 \mathrm{CSF}$ samples were positive for multiplex-PCR (Table 4). All 389 CSF samples from this group presented some biochemical, microbiological (bacterioscopy), immunological (latex agglutination), or hematological alterations suggestive of bacterial meningitis (number of leukocytes above 100 cells $/ \mathrm{mm}^{3}$, percentage of neutrophils above $50 \%$, glucose below $40 \mathrm{mg} / \mathrm{dL}$, lactate above $40 \mathrm{mg} / \mathrm{dL}$, and protein above $40 \mathrm{mg} / \mathrm{dL}$ ) (Table 2). In the $13 \mathrm{CSF}$ samples from group II that were positive for multiplex-PCR, three $N$. meningitidis, three $S$. pneumoniae, and one $S$. agalactiae were detected. The other six CSF samples were positive only for the $16 S r R N A$ gene, evidencing the presence of another bacterial pathogen (Table 4). All these 13 patients presented clinical evidences of meningitis, with significant biochemical and cellular alterations in the CSF samples (Table 5). No samples from group III were multiplex-PCR positive (Table 4). These samples were physiologically and biochemically normal (Table 2 ) and were negative for bacterial culture (Table 4).

The multiplex-PCR diagnostic test demonstrated an overall PPA of $100 \%$ (27/27) and NPA of $96.7 \%$ (407/420) when the results were compared with the non-reference standard, which was the isolation of pathogens by the routine microbiological culture. The test showed a substantial correlation (kappa, 


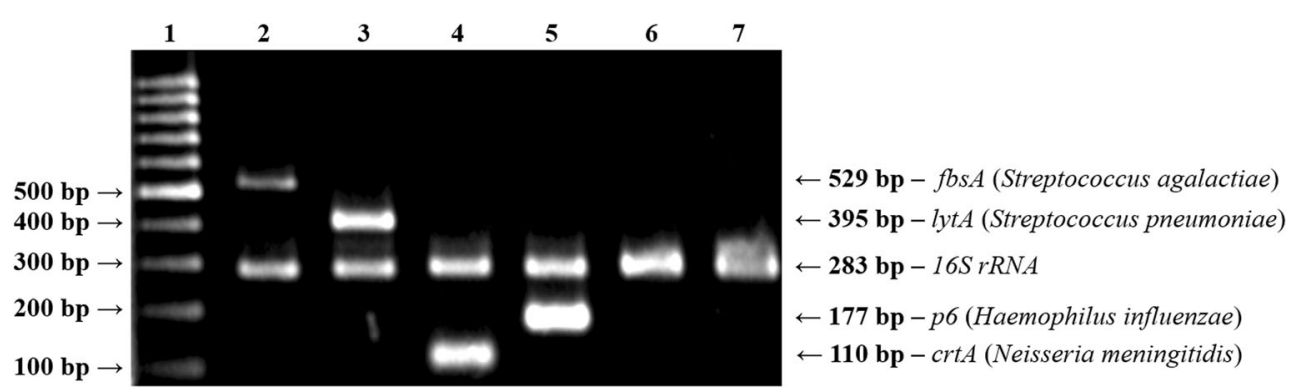

Fig. 1 Multiplex-PCR to determine bacterial pathogens related to meningitis. Electrophoretic separation of amplicons from multiplexPCR developed for the detection of four bacterial species: Streptococcus agalactiae, Streptococcus pneumoniae, Haemophilus influenzae, and Neisseria meningitidis. 1-molecular weight marker of $100 \mathrm{bp}, 2$-Streptococcus agalactiae (fbsA gene, 529 bp and $16 \mathrm{~S} r R N A$

$0.791 ; 95 \% \mathrm{CI})$ with the conventional methods for the detection of bacterial in CSF specimens from meningitis-suspected patients. Additionally, the multiplex-PCR diagnostic test approach takes approximately $3 \mathrm{~h}$ for the release of the clinical result. The non-standard method of microbiological culture takes from 3 to 7 days for the detection of specific meningitis bacterial pathogens.

\section{Discussion}

In the present work, we develop a rapid and accurate multiplex-PCR for simultaneous detection of $S$. pneumoniae, $H$. influenzae, $S$. agalactiae, $N$. meningitides, and other possible bacterial pathogens directedly in CSF samples, without prior extraction of bacterial DNA by commercial kit. The multiplex-PCR was inexpensive, affordable, sensitive, and specific, detecting small amount of DNA samples, and did not cross-react with fungi or other bacterial pathogens. Moreover, our multiplex-PCR test was more sensible than bacterial culture, providing the identification of bacterial pathogens in culture-negative CSF samples in $3 \mathrm{~h}$. This molecular gene, 283 bp), 3-Streptococcus pneumoniae (lytA gene, 395 bp and $16 S$ rRNA gene, $283 \mathrm{bp}$ ), 4-Neisseria meningitidis (crtA gene, $110 \mathrm{bp}$ and $16 S$ rRNA gene, $283 \mathrm{bp}$ ), 5-Haemophilus influenzae (p6 gene, $177 \mathrm{bp}$ and $16 S$ rRNA gene, $283 \mathrm{bp}), 6$ - Escherichia coli (16S rRNA gene, 283 bp), 7-Listeria monocytogenes (16S rRNA gene, 283 bp). bp, base pairs

approach increases the quantification of the etiology for meningitis, and enabling the detection after antibiotic treatment has been installed.

Bacterial meningitis is a serious and often fatal infection that affects the CNS. Microbiological culture, Gram staining, and latex agglutination tests have been routinely used in the detection and identification of CSF bacteria [1]. However, the definitive diagnosis of bacterial meningitis is only obtained after the conclusion of the culture, around $72 \mathrm{~h}$. The sensitivity of these preliminary analyzes is affected by several factors such as detection threshold, sample quality and quantity of microorganisms in the clinical sample [9]. In fact, the sensitivity of the bacterial culture technique in CSF samples is around $85 \%$ in patients without antimicrobial therapy $[1,9$, $10]$. Moreover, there is approximately a $30 \%$ reduction in the identification of the etiology of meningitis when the patient is under antimicrobial therapy prior to lumbar puncture, since antimicrobials inhibit bacterial growth in the microbial culture media [12]. Molecular approaches can subvert these recurring clinical laboratory problems due to their greater sensitivity in the detection of smaller number of bacteria in the clinical sample, which do not necessarily have to be viable.

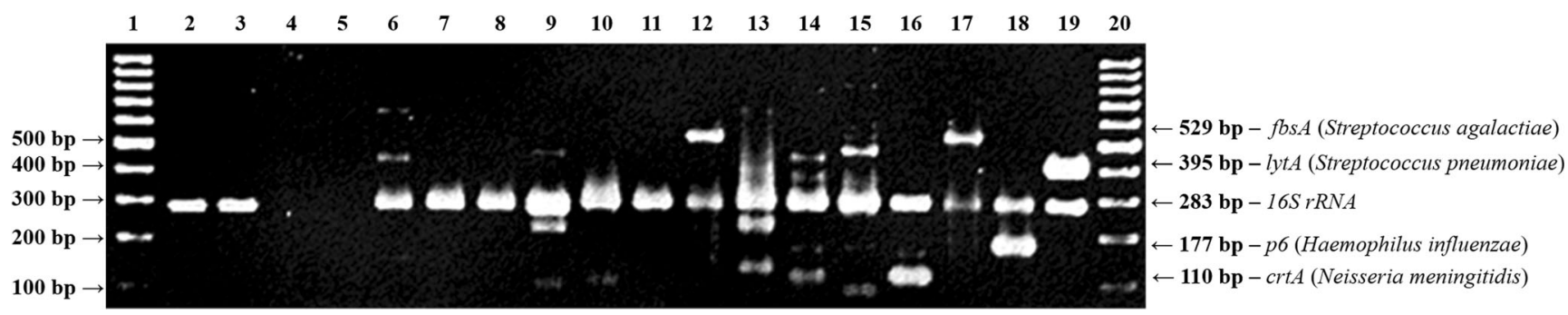

Fig. 2 Multiplex-PCR performed with different microorganisms. Lysates of different bacterial species and CSF samples positive for Candida albicans and Cryptococcus neoformans were tested by the multiplexPCR. The electrophoretic separation was performed in agarose gel. 1molecular weight marker of $100 \mathrm{bp}, 2$-Enterococcus faecalis, 3Streptococcus pyogenes, 4-Cryptococcus neoformans, 5-Candida albicans, 6-Staphylococcus aureus, 7-Escherichia coli, 8Salmonella typhi, 9-Pseudomonas aeruginosa, 10-Shigella flexneri, 11-Listeria monocytogenes, 12-Streptococcus agalactiae, 13-
Klebsiella pneumoniae, 14-Citrobacter diversus, 15-Neisseria gonorrhoeae, 16-Neisseria meningitidis, 17-Streptococcus agalactiae, 18-Haemophilus influenzae, 19-Streptococcus pneumoniae, 20 -molecular weight marker of $100 \mathrm{bp}$. Amplicons size correspond to Streptococcus agalactiae - $f b s A$ gene (529 bp), Streptococcus pneumoniae-lytA gene (395 bp), 16S rRNA gene (283 bp), Haemophilus influenzae - p6 gene (177 bp), Neisseria meningitidis — crtA gene (110 bp). bp, base pairs 


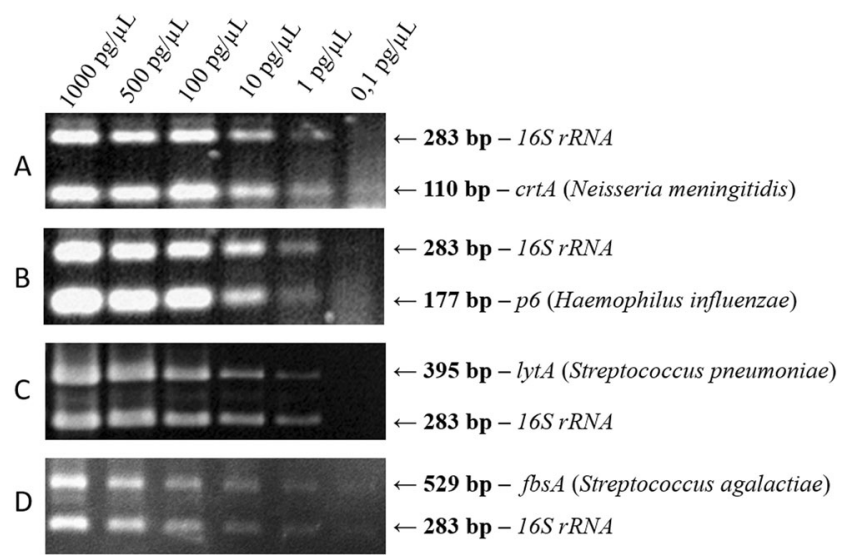

Fig. 3 Sensitivity test of the multiplex-PCR performed with serial dilutions of DNA extracted by Kit. Different dilutions of bacterial DNA were tested in the reaction of multiplex-PCR to evaluate the sensitivity of the method. The electrophoretic separation was performed in agarose gel. The figure illustrates the testing of (A) Neisseria meningitidis (crtA gene, $110 \mathrm{bp}$ and $16 \mathrm{~S}$ rRNA gene, $283 \mathrm{bp}$ ), (B) Haemophilus influenzae (p6 gene, $177 \mathrm{bp}$ and $16 \mathrm{~S}$ rRNA gene, $283 \mathrm{bp}$ ), (C) Streptococcus pneumoniae (lytA gene, $395 \mathrm{bp}$ and $16 S$ rRNA gene, $283 \mathrm{bp}$ ), and (D) Streptococcus agalactiae ( $f b s A$ gene, 529 bp and $16 S$ rRNA gene, $283 \mathrm{bp}$ ). The gel columns represent different DNA concentrations, as specified in the figure, with the following concentrations from the left to right: $1000 \mathrm{pg} / \mu \mathrm{L}, 500 \mathrm{pg} / \mu \mathrm{L}, 100 \mathrm{pg} / \mu \mathrm{L}, 10 \mathrm{pg} / \mu \mathrm{L}, 1 \mathrm{pg} / \mu \mathrm{L}, 0.1 \mathrm{pg} /$ $\mu \mathrm{L}$. bp, base pairs

Additionally, the detection of the pathogen can be performed while the patient is under treatment [13, 14, 19-23].

The multiplex-PCR proposed here combines five different pairs of primers that simultaneously detect the $N$. meningitidis crtA gene, the $H$. influenzae $p 6$ gene, the $S$. agalactiae $f b s A$ gene, the $S$. pneumoniae lytA gene, and the universal $16 S$ $r R N A$ gene that detect the presence of any bacterial agent. The gene selected for the identification of $H$. influenzae

Table 4 Detection of bacterial pathogens by multiplex-PCR in CSF samples

\begin{tabular}{llll}
\hline Groups & Bacterial culture & $\begin{array}{l}\text { Multiplex- } \\
\text { PCR }\end{array}$ & No. of samples \\
\hline G I & N. meningitidis & N. meningitidis & 11 \\
& S. pneumoniae & S. pneumoniae & 13 \\
& K. pneumoniae & 16S rDNA & 1 \\
& Pseudomonas aeruginosa & 16S rDNA & 2 \\
G I Total & & & 27 \\
G II & Negative & Negative & 376 \\
& Negative & N. meningitidis & 3 \\
& Negative & S. agalactiae & 1 \\
& Negative & S. pneumoniae & 3 \\
G II Total & Negative & 16S rDNA & 6 \\
G III & Negative & & 389 \\
G III Total & & Negative & 31 \\
Total & & & 31 \\
\hline
\end{tabular}

encodes an outer membrane protein P6 (OMP P6), designated $p 6$ gene, found in all capped and uncapsulated serotypes [24]. The OMP P6 is highly conserved among geographically unrelated $H$. influenzae strains [25] and different studies use this gene in the molecular identification of $H$. influenzae $[13,26$, 27]. The $c r t A$ gene, which encodes a capsule transport protein, was selected for the identification of $N$. meningitidis. The sequences of the primers for this gene were proposed by Corless and collaborators [12]. These authors developed a multiplex real-time PCR method for the diagnosis of meningitis and septicemia, where it was possible to amplify the $\mathrm{crtA}$ gene in serogroups A, B, C, X, Y, Z, 29H, W135, and nonserum-clustered species. In the literature, there are several studies that have used this gene, as well as genes necessary for capsid biosynthesis (species-specific) for the identification and typing of $N$. meningitidis $[13,14,19,22,23]$. The gene selected for the identification of $S$. agalactiae was $f b s A$, which encodes a protein that binds to fibrinogen, present in $90 \%$ of the strains [28]. The primers for $f b s A$ used in the reaction did not cross-react with $S$. pneumoniae and $S$. pyogenes DNA, allowing the correct differentiation of the two species of streptococci present in the reaction. The lytA gene was selected for the identification of $S$. pneumoniae due to its greater sensitivity and specificity, since it is conserved among S. pneumoniae strains and presents limited genetic variation ( 0.11 to $0.32 \%)$ [29]. Additionally, several studies also use the lytA gene for molecular identification of $S$. pneumoniae strains [14, 19, 23].

In the literature, different studies address the identification of important bacterial pathogens related to meningitis by molecular biology techniques. Among the most commonly used techniques are multiplex-PCR and multiplex real-time PCR $[13-15,19,22,23]$. Most studies address the simultaneous identification of three pathogenic species, such as $N$. meningitidis, S. pneumoniae, and $H$. influenzae. Additionally, the method of obtaining bacterial DNA from CSF samples is usually done by DNA extraction with commercial kits, which adds time and value to the diagnostic method, besides the need for a larger volume of clinical sample, from 100 to $1000 \mu \mathrm{L}$. In the multiplex-PCR proposed here, we were able to do the reaction from $20 \mu \mathrm{L}$ of CSF, and the clinical sample was only boiled and then cooled for later use in the PCR reaction. This is one of the great advantages of our multiplex-PCR test, since it is inexpensive and affordable to be applied in different types of clinical laboratories. Furthermore, our multiplex-PCR test can detect the leading etiological causes of meningitis around the world, being $N$. meningitidis, $H$. influenzae, S. pneumoniae, and $S$. agalactiae, while it is able to detect the presence of any other bacterial pathogen in the CSF sample due to the presence of the pair of primers for $16 \mathrm{~S} \mathrm{rRNA}$ gene. The $16 \mathrm{~S} \mathrm{rRNA}$ gene is as well a tool for an internal control of the reaction.

There are some commercial multiplex molecular panels for the diagnosis of infectious meningitis. The FilmArray ${ }^{\circledR}$ 
Table 5 Clinical and laboratory data from 13 patients with negative culture and positive multiplex-PCR

\begin{tabular}{|c|c|c|c|c|c|}
\hline Patient & Age & Clinical suspicion & $\begin{array}{l}\text { Previous } \\
\text { treatments }\end{array}$ & Clinical parameters & Multiplex-PCR \\
\hline P1 & $\begin{array}{l}\text { 3-year-old } \\
\text { male }\end{array}$ & $\begin{array}{l}\text { Meningococcal } \\
\text { meningitis }\end{array}$ & Yes & $\begin{array}{l}\text { Cytology } 5.600 / \mathrm{mm}^{3} \text {, lymphocytes } 1 \% \text {, monocytes } 3 \% \text {, } \\
\text { neutrophils } 96 \% \text {, glucose } 71 \mathrm{mg} / \mathrm{dL} \text {, latic acid } 25 \mathrm{mg} / \mathrm{dL}, \\
\text { protein } 26.7 \mathrm{mg} / \mathrm{dL}\end{array}$ & $\begin{array}{l}\text { crtA, } 16 S \text { rDNA } \\
\text { (N.meningitidis) }\end{array}$ \\
\hline $\mathrm{P} 2$ & $\begin{array}{l}\text { 17-year-old } \\
\text { male }\end{array}$ & Not stated & Yes & $\begin{array}{l}\text { Cytology } 5.330 / \mathrm{mm}^{3} \text {, lymphocytes } 4 \% \text {, monocytes } 18 \% \text {, } \\
\text { neutrophils } 78 \% \text {, glucose } 0 \mathrm{mg} / \mathrm{dL} \text {, latic acid } 23.1 \mathrm{mg} / \mathrm{dL} \text {, } \\
\text { protein } 83 \mathrm{mg} / \mathrm{dL}\end{array}$ & $\begin{array}{l}\text { crtA, } 16 S \text { rDNA } \\
\quad \text { (N. meningitidis) }\end{array}$ \\
\hline P3 & $\begin{array}{l}\text { 9-year-old } \\
\text { female }\end{array}$ & $\begin{array}{l}\text { Meningococcal } \\
\text { meningitis }\end{array}$ & No & $\begin{array}{l}\text { Cytology } 395 / \mathrm{mm}^{3} \text {, lymphocytes } 1 \% \text {, neutrophils } 99 \% \text {, glucose } \\
19 \mathrm{mg} / \mathrm{dL} \text {, latic acid } 174.7 \mathrm{mg} / \mathrm{dL} \text {, protein } 473.2 \mathrm{mg} / \mathrm{dL}, \\
\text { hemoculture positive for } N . \text { meningitidis }\end{array}$ & $\begin{array}{l}\text { crtA, } 16 S \text { rDNA } \\
\quad \text { (N. meningitidis) }\end{array}$ \\
\hline $\mathrm{P} 4$ & $\begin{array}{l}\text { 69-year-old } \\
\text { female }\end{array}$ & Not stated & Not stated & $\begin{array}{l}\text { Cytology } 45.696 / \mathrm{mm}^{3}, \text { neutrophils } 98 \% \text {, glucose } 3 \mathrm{mg} / \mathrm{dL} \text {, } \\
\text { latic acid } 118.4 \mathrm{mg} / \mathrm{dL}\end{array}$ & $\begin{array}{l}\text { lytA, } 16 S \text { rDNA } \\
\quad \text { (S. pneumoniae) }\end{array}$ \\
\hline P5 & $\begin{array}{l}\text { 7-month-old } \\
\text { female }\end{array}$ & Not stated & Not stated & $\begin{array}{l}\text { Cytology } 17.600 / \mathrm{mm}^{3} \text {, neutrophils } 98 \% \text {, presence of } \\
\text { gram-positive cocci, hemoculture positive for S. pneumoniae }\end{array}$ & $\begin{array}{l}\text { lytA, } 16 S \text { rDNA } \\
\quad \text { (S. pneumoniae) }\end{array}$ \\
\hline P6 & $\begin{array}{l}\text { 1-year-old } \\
\text { masculino }\end{array}$ & Bacterial meningitis & No & $\begin{array}{l}\text { Cytology } 364 / \mathrm{mm}^{3} \text {, lymphocytes } 5 \% \text {, monocytes } 6 \% \text {, } \\
\text { neutrophils } 89 \text {, glucose } 1 \mathrm{mg} / \mathrm{dL} \text {, latic acid } 107.7 \mathrm{mg} / \mathrm{dL} \text {, } \\
\text { protein } 171 \mathrm{mg} / \mathrm{dL} \text {, positive latex agglutination }\end{array}$ & $\begin{array}{l}\text { lytA, } 16 S \text { rDNA } \\
\quad \text { (S. pneumoniae) }\end{array}$ \\
\hline P7 & $\begin{array}{l}\text { Newborn } \\
\text { male }\end{array}$ & Sepsis & No & $\begin{array}{c}\text { Cytology } 84 / \mathrm{mm}^{3}, \text { lymphocytes } 13 \% \text {, monocytes } 80 \%, 7 \% \\
\text { neutrophils, glucose } 106 \mathrm{mg} / \mathrm{dL} \text {, latic acid } 23.5 \mathrm{mg} / \mathrm{dL}\end{array}$ & $\begin{array}{l}f b s A, 16 S \text { rDNA } \\
\quad \text { (S. agalactiae) }\end{array}$ \\
\hline P8 & $\begin{array}{l}\text { Newborn } \\
\text { female }\end{array}$ & $\begin{array}{l}\text { Hypotonic and with } \\
\text { central cyanosis }\end{array}$ & No & $\begin{array}{l}\text { Cytology } 10 / \mathrm{mm}^{3} \text {, lymphocytes } 6 \% \text {, monocytes } 68 \% \text {, } \\
\text { neutrophils } 26 \% \text {, glucose } 61 \mathrm{mg} / \mathrm{dL} \text {, latic acid } 24.4 \mathrm{mg} / \mathrm{dL} \text {, } \\
\text { protein } 58.4 \mathrm{mg} / \mathrm{dL}\end{array}$ & $16 S r D N A$ \\
\hline P9 & $\begin{array}{l}\text { 10-day-old } \\
\text { male }\end{array}$ & $\begin{array}{l}\text { Sepsis fever } 38^{\circ} \mathrm{C} \text { upper } \\
\quad \text { airways infections }\end{array}$ & No & $\begin{array}{l}\text { Cytology } 960 / \mathrm{mm}^{3}, \text { lymphocytes } 14 \% \text {, monocytes } 6 \% \text {, } \\
\text { neutrophils } 74 \% \text {, glucose } 57 \mathrm{mg} / \mathrm{dL} \text {, latic acid } 21 \mathrm{mg} / \mathrm{dL} \text {, } \\
\text { protein } 318 \mathrm{mg} / \mathrm{dL}\end{array}$ & $16 S r D N A$ \\
\hline $\mathrm{P} 10$ & $\begin{array}{l}\text { 36-year-old } \\
\text { male }\end{array}$ & $\begin{array}{l}\text { Chronic meningitis } \\
\text { Behcet's disease }\end{array}$ & No & $\begin{array}{l}\text { Cytology } 134 / \mathrm{mm}^{3}, \text { lymphocytes } 29 \% \text {, monocytes } 5 \% \text {, } \\
\text { neutrophils } 66 \% \text {, glucose } 46 \mathrm{mg} / \mathrm{dL} \text {, latic acid } 17.4 \mathrm{mg} / \mathrm{dL} \text {, } \\
\text { protein } 133.7 \mathrm{mg} / \mathrm{dL}\end{array}$ & $16 S r D N A$ \\
\hline P11 & $\begin{array}{l}\text { 26-year-old } \\
\text { male }\end{array}$ & $\begin{array}{l}\text { Bronchodysplasia } \\
\text { intracranial } \\
\text { hemorrhage }\end{array}$ & No & $\begin{array}{l}\text { Cytology: } 9 / \mathrm{mm}^{3} \text {, lymphocytes } 23 \% \text {, monocytes } 73 \% \text {, } \\
\text { neutrophils } 4 \% \text {, glucose: } 56 \mathrm{mg} / \mathrm{dL} \text {, latic acid: } 10,9 \mathrm{mg} / \mathrm{dL} \text {, } \\
\text { protein: } 58,1 \mathrm{mg} / \mathrm{dL}\end{array}$ & $16 S r D N A$ \\
\hline $\mathrm{P} 12$ & $\begin{array}{l}\text { 32-year-old } \\
\text { male }\end{array}$ & Bacterial meningitis & Yes & $\begin{array}{l}\text { Cytology } 130 / \mathrm{mm}^{3} \text {, glucose } 76 \mathrm{mg} / \mathrm{dL} \text {, latic acid } 20 \mathrm{mg} / \mathrm{dL} \text {, } \\
\text { protein } 32 \mathrm{mg} / \mathrm{dL} \text {, hemoculture positive for A. baumannii }\end{array}$ & $16 S r D N A$ \\
\hline $\mathrm{P} 13$ & $\begin{array}{l}\text { 32-year-old } \\
\text { male }\end{array}$ & Bacterial meningitis & Yes & $\begin{array}{l}\text { Cytology } 101 / \mathrm{mm}^{3} \text {, glucose } 73 \mathrm{mg} / \mathrm{dL} \text {, latic acid } 18 \mathrm{mg} / \mathrm{dL} \text {, } \\
\text { protein } 25 \mathrm{mg} / \mathrm{dL} \text {, hemoculture positive for A. baumannii }\end{array}$ & $16 S r D N A$ \\
\hline
\end{tabular}

Meningitis/Encephalitis (ME) panel (BioFire Diagnostics, Salt Lake City, UT) was recently tested by Liesman and collaborators [20]. This commercial kit covers the detection of 14 important pathogens in meningitis, being six bacteria, seven viruses, and one fungus. Although sensitive and specific, there is a need for skilled labor, in addition to the price being inaccessible to various laboratories. Wagner and collaborators developed a multiplex LightMix real-time PCR assay with commercially available LightMix primers and probes (TIB Molbiol, Berlin, Germany) to detect S. pneumoniae, $H$. influenzae, $N$. meningitidis, S. agalactiae, and L. monocytogenes in CSF samples [21]. However, in the range of samples studied, only $S$. pneumoniae, $N$. meningitidis, and $S$. agalactiae were found. Nevertheless, the multiplex LightMix real-time PCR assay proved to be valuable in the diagnosis of bacterial meningitis. It is important to point out that for these two studies, a large volume of clinical sample is required to obtain microbial DNA by commercial kit extraction $[20,21]$.
Importantly, our multiplex-PCR did not present nonspecific reactions with $C$. neoformans and $C$. albicans, or with bacterial isolates from other clinical samples, demonstrating $100 \%$ specificity. The sensitivity of the diagnostic method was evaluated with serial dilutions of bacterial DNA, and we observed that the lowest detectable concentration of DNA for all bacterial samples was $1 \mathrm{pg} / \mu \mathrm{L}$. The sensitivity of the method was also evaluated in the absence of the pair of primer for the $16 S r R N A$ gene to verify a possible increment in the efficiency of the reaction. However, the results obtained were the same, with no variation in the detection sensitivity of the bacterial agents (data not shown). This observation was very significant, since the presence of a pair of primers for the detection of the $16 \mathrm{~S} r R N A$ gene not only differentiates the proposed assay from others existing in the literature but also increases the probability of detecting other bacterial etiological agents present in the CSF samples, differently from $H$. influenzae, $N$. meningitidis, $S$. agalactiae, and $S$. pneumoniae. Therefore, the use of a pair of primer for the 16S rRNA gene 
in the multiplex-PCR assists in the screening of bacterial etiology for meningitis.

The multiplex-PCR assay was applied in $447 \mathrm{CSF}$ samples, where 27 samples were culture-positive. Multiplex-PCR detected all positive samples from G I group and 13 samples belonging to G II group. All samples from G III group were negative for the multiplex-PCR assay, as well as for bacterial culture. Therefore, all culture-positive and bacterioscopypositive (Gram staining) CSF samples were also positive for multiplex-PCR, showing that this method was $100 \%$ sensitive. The 13 samples with positive results for multiplexPCR, but with culture-negative, presented some cytological, biochemical, immunological, and/or microbiological alterations (bacterioscopy-positive) suggestive of meningitis (Table 5). It is important to emphasize that these 13 patients were under antibiotic therapy. The microorganisms identified by the multiplex-PCR were the same as the bacteriological features, as Gram staining, positive latex agglutination, or hemoculture-positive. These laboratory data helped us to confirm the results obtained in the molecular assay, such as the presence of positive samples for bacterioscopy (P5S. pneumoniae), blood culture ( $\mathrm{P} 3-N$. meningitidis, $\mathrm{P} 5-$ S. pneumoniae), or latex agglutination (P6-S. pneumoniae). For other four patients, there was clinical suspicion of meningitis or sepsis, but the microbiological culture was negative, as was bacterioscopy and the latex agglutination test (P1$N$. meningitidis, $\mathrm{P} 2-N$. meningitidis, $\mathrm{P} 4-S$. pneumoniae, P7-S. agalactiae). Additionally, six samples were positive only for $16 S r R N A$ gene. Two of them presented blood culture positive for Acinetobacter baumannii (P12 and P13), and the other four could not be identify by sequencing due to insufficient sample (P8-P11). Overall, the multiplex-PCR diagnostic test demonstrated an excellent diagnostic accuracy, with a good correlation with the conventional culture routine testing, detecting $100 \%$ of all bacterial pathogens included to the test (PPA 100\%). Additionally, the high NPA obtained (96.9\%) indicates that the true negative results could be reliable and associated with the absence of the meningitis disease. The discrepant analysis regarding the negative result from nonstandard test compared with the multiplex-PCR diagnostic test (13 samples) emphasizes the use of molecular approach for the detection of meningitis bacterial pathogens in urgent, since patients cannot delay antibiotic therapy based on the microbiological diagnosis.

The $H$. influenzae was not found. After the introduction of vaccine against $H$. influenzae type $\mathrm{b}$ in children between 2 months and 5 years of age by the Brazilian Health Public Service, it was possible to observe a strong decrease of the $H$. influenzae incidence among Brazilian children. It is important to note that of the samples belonging to the G II group (Table 2), 40 were PCR positive for virus, being 33 samples positive for Enterovirus and 7 samples for Herpes virus (dos Santos, D. C. et al., 2012-poster presented at XXI Congresso
Latinoamericano de Microbiologia, Mendes Conventional Center, Santos, São Paulo, Brazil, October 28 to November 1st).

As well as in our study, the identification of pathogens from CSF negative culture samples has already been observed by others [14, 15, 21], evidencing the need of the incorporation of molecular biology techniques in the diagnosis of the etiology of meningitis in clinical laboratories. Evaluation of the culture-negative samples using the molecular assay provided an increase in etiology detection and saves time of result releasing as compared with the conventional techniques, allowing the beginning of patient treatment and, consequently, decreasing the probability of worsening of the patient's clinical condition.

Multiplex-PCR is a simple, fast, and reliable method that allows the analysis of a large number of samples. Moreover, it may assist in the diagnosis of meningitis with negative CSF culture, either by the suspicion of meningitis or some other pathologies and particularly for patients who have previously initiated antimicrobial therapy. Furthermore, multiplex-PCR may aid in the differential diagnosis between bacterial and viral meningitis, where the results of conventional methods are inconclusive. Multiplex-PCR is an important tool for the early diagnosis of bacterial meningitis and can provide important epidemiological data, assisting in the implementation of vaccination schemes and in blocking transmission. The Multiplex-PCR proposed in this study has as a differential the ability to simultaneously identify four important etiologic agents of bacterial meningitis directly from the clinical sample, without the need for DNA extraction by commercial kits, which makes this test more affordable to most clinical laboratories. Additionally, by the incorporation of 16S rRNA gene to the PCR reaction, it is possible to detect the presence of other possible bacterial pathogens.

Author contributions Conceptualization: MBM. Data curation: RCA, ACRM, SRS, and SLBR. Formal analysis: RCA, ACRM, and MBM. Funding acquisition: MBM. Investigation: RCA, ACRM, and MBM. Project administration: MBM. Resources: MBM. Supervision: MBM and ACRM. Validation: RCA and ACRM. Visualization: RCA and ACRM. Writing - original draft: RCA, ACRM, and MBM. Writing review and editing: MBM and ACRM.

Funding information This work was funded by grants 2006/55141-4 from Fundação de Amparo à Pesquisa do Estado de São Paulo (FAPESP). A.C.R.M. was awarded scholarship grants by the Brazilian Federal Agency for Support and Evaluation of Graduate Education (Coordenação de Aperfeiçoamento de Pessoal de Nível Superior CAPES).

\section{Compliance with ethical standards}

This study was approved by the Ethics Committee of the HU-USP (protocol number 45904) and the IIER (protocol number 3807).

Conflict of interest The authors declare that they have no conflicts of interest. 
Publisher's note Springer Nature remains neutral with regard to jurisdictional claims in published maps and institutional affiliations.

\section{References}

1. Brouwer MC, Tunkel AR, Van De Beek D (2010) Epidemiology, diagnosis, and antimicrobial treatment of acute bacterial meningitis. Clin Microbiol Rev 23:467-492. https://doi.org/10.1128/CMR. 00070-09.

2. Van De Beek D, Brouwer M, Hasbun R, Koedel U, Whitney CG, Wijdicks E (2016) Community-acquired bacterial meningitis. Nat Rev Dis Primers 2:16074. https://doi.org/10.1038/nrdp.2016.74

3. van de Beek D, Drake JM, Tunkel AR (2010) Nosocomial bacterial meningitis. N Engl J Med 362:146-154. https://doi.org/10.1056/ NEJMra0804573

4. Kim KS (2010) Acute bacterial meningitis in infants and children. Lancet Infect Dis 10:32-42. https://doi.org/10.1016/S14733099(09)70306-8

5. van de Beek D, de Gans J, Tunkel AR, Wijdicks EFM (2006) Community-acquired bacterial meningitis in adults. N Engl J Med 100:37-40. https://doi.org/10.1093/qjmed/hcl131.

6. Saez-Llorens X, McCracken GH Jr (2003) Bacterial meningitis in children. Lancet. 361:2139-2148. https://doi.org/10.1016/S01406736(03)13693-8

7. Philip AGS (2009) Neonatal bacterial meningitis. In: Fetal and neonatal brain injury, 4th edn. https://doi.org/10.1017/ CBO9780511581281.033

8. McGill F, Heyderman RS, Panagiotou S, Tunkel AR, Solomon T (2016) Acute bacterial meningitis in adults. Lancet. 388:30363047. https://doi.org/10.1016/S0140-6736(16)30654-7

9. Heckenberg SGB, Brouwer MC, van de Beek D (2014) Bacterial meningitis. Handb Clin Neurol. https://doi.org/10.1016/B978-07020-4088-7.00093-6

10. Van De Beek D, Brouwer MC, Thwaites GE, Tunkel AR (2012) Advances in treatment of bacterial meningitis. Lancet. 380:16931702. https://doi.org/10.1016/S0140-6736(12)61186-6

11. Mohammadi SF, Patil AB, Nadagir SD, Nandihal N, Lakshminarayana SA (2013) Diagnostic value of latex agglutination test in diagnosis of acute bacterial meningitis. Ann Indian Acad Neurol 16:645-649. https://doi.org/10.4103/0972-2327.120491

12. Corless CE, Guiver M, Borrow R, Edwards-Jones V, Fox AJ, Kaczmarski EB (2001) Simultaneous detection of Neisseria meningitidis, Haemophilus influenzae, and Streptococcus pneumoniae in suspected cases of meningitis and septicemia using real-time PCR. J Clin Microbiol 39:1553-1558. https://doi.org/10. 1128/JCM.39.4.1553-1558.2001

13. Abdeldaim GMK, Strålin K, Korsgaard J, Blomberg J, WelinderOlsson C, Herrmann B (2010) Multiplex quantitative PCR for detection of lower respiratory tract infection and meningitis caused by Streptococcus pneumoniae, Haemophilus influenzae and Neisseria meningitidis. BMC Microbiol 10:310. https://doi.org/10.1186/ 1471-2180-10-310

14. Sacchi CT, Fukasawa LO, Gonçalves MG, Salgado MM, Shutt KA, Carvalhanas TR, Ribeiro AF, Kemp B, Gorla MCO, Albernaz RK, Marques EGL, Cruciano A, Waldman EA, Brandileone MCC, Harrison LH, São Paulo RT-PCR Surveillance Project Team (2011) Incorporation of real-time PCR into routine public health surveillance of culture negative bacterial meningitis in São Paulo, Brazil. PLoS One 6:e20675. https://doi.org/10.1371/journal.pone.0020675

15. Chakrabarti P, Das BK, Kapil A (2009) Application of 16S rDNA based seminested PCR for diagnosis of acute bacterial meningitis. Indian J Med Res

16. de Zoysa A, Edwards K, Gharbia S, Underwood A, Charlett A, Efstratiou A (2012) Non-culture detection of Streptococcus agalactiae (Lancefield group B Streptococcus) in clinical samples by real-time PCR. J Med Microbiol 61:1086-1090. https://doi.org/ 10.1099/jmm.0.042879-0

17. Messmer TO, Black CM, Facklam RR (1995) Discrimination of Streptococcus pneumoniae from other upper respiratory tract streptococci by arbitrarily primed PCR. Clin Biochem 28:567-572. https://doi.org/10.1016/0009-9120(95)00044-0

18. McHugh ML (2012) Interrater reliability: the kappa statistic. Biochem Med:276-282. https://doi.org/10.11613/BM.2012.031

19. Wang X, Theodore MJ, Mair R, Trujillo-Lopez E, du Plessis M, Wolter N, Baughman AL, Hatcher C, Vuong J, Lott L, von Gottberg A, Sacchi C, McDonald JM, Messonnier NE, Mayer LW (2012) Clinical validation of multiplex real-time PCR assays for detection of bacterial meningitis pathogens. J Clin Microbiol 50: 702-708. https://doi.org/10.1128/JCM.06087-11

20. Liesman RM, Strasburg AP, Heitman AK, Theel ES, Patel R, Binnicker MJ (2018) Evaluation of a commercial multiplex molecular panel for diagnosis of infectious meningitis and encephalitis. J Clin Microbiol 56:e01927-e01917. https://doi.org/10.1128/JCM.01927-17

21. Wagner K, Springer B, Pires VP, Keller PM (2017) Pathogen identification by multiplex LightMix real-time PCR assay in patients with meningitis and culture-negative cerebrospinal fluid specimens. J Clin Microbiol 56. https://doi.org/10.1128/JCM.01492-17

22. Seth R, Murthy PSR, Sistla S, Subramanian M, Tamilarasu K (2017) Rapid and accurate diagnosis of acute pyogenic meningitis due to streptococcus pneumoniae, Haemophilus influenzae type $b$ and Neisseria meningitis using a multiplex PCR assay. J Clin Diagn Res. https://doi.org/10.7860/JCDR/2017/28114.10532

23. Khumalo J, Nicol M, Hardie D, Muloiwa R, Mteshana P, Bamford C (2017) Diagnostic accuracy of two multiplex real-time polymerase chain reaction assays for the diagnosis of meningitis in children in a resource-limited setting. PLoS One 12:e173948. https://doi. org/10.1371/journal.pone.0173948

24. Billal DS, Hotomi M, Suzumoto M, Yamauchi K, Kobayashi I, Fujihara K, Yamanaka N (2007) Rapid identification of nontypeable and serotype $\mathrm{b}$ Haemophilus influenzae from nasopharyngeal secretions by the multiplex PCR. Int J Pediatr Otorhinolaryngol 71:269 274. https://doi.org/10.1016/j.ijporl.2006.10.009

25. Nelson MB, Munson RS, Apicella MA, Sikkema DJ, Molleston JP, Murphy TF (1991) Molecular conservation of the P6 outer membrane protein among strains of Haemophilus influenzae: analysis of antigenic determinants, gene sequences, and restriction fragment length polymorphisms. Infect Immun 59(8):2658-2663

26. Khazani NA, Noor NZNM, Yean C, Hasan H, Suraiya S, Mohamad S (2017) A thermostabilized, one-step PCR assay for simultaneous detection of Klebsiella pneumoniae and Haemophilus influenzae. J Trop Med 2017:1-8. https://doi.org/10.1155/2017/7210849

27. de Filippis I, de Andrade CF, Caldeira N, de Azevedo AC, de Almeida AE (2016) Comparison of PCR-based methods for the simultaneous detection of Neisseria meningitidis, Haemophilus influenzae, and Streptococcus pneumoniae in clinical samples. Braz J Infect Dis 20: 335-341. https://doi.org/10.1016/j.bjid.2016.04.005

28. Lindahl G, Stålhammar-Carlemalm M, Areschoug T (2005) Surface proteins of Streptococcus agalactiae and related proteins in other bacterial pathogens. Clin Microbiol Rev 18:102-127. https://doi.org/10.1128/CMR.18.1.102-127.2005.

29. Whatmore AM, Dowson CG (1999) The autolysin-encoding gene (lytA) of Streptococcus pneumoniae displays restricted allelic variation despite localized recombination events with genes of pneumococcal bacteriophage encoding cell wall lytic enzymes. Infect Immun 